\title{
AS FUNDAÇÕES PÚBLICAS E O NOVO CÓDIGO CIVIL
}

\author{
AlexandRe SANTOS DE ARAGão*
}

I - INTRODUÇÃO. II - AS FUNDAÇÕES NA TEORIA GERAL DO DIREITO E NO DIREITO PRIVADO. III - AS FUNDAÇÕES NO DIREITO PÚBLICO. III.1 - A personalidade jurídica de Direito Público e a Descentralização Administrativa. III.2 - Natureza Jurídica das Fundações Públicas. IV - O NOVO CÓDIGO CIVIL. V - CONCLUSÕES. VI BIBLIOGRAFIA.

\section{I- Introdução}

O tema das fundações instituídas pelo Estado — ditas fundações públicas — 1 é um dos pontos do Direito que mais revela as interseções entre o Direito Público e o Direito Privado, que têm levado a uma forte atenuação da separação destes dois principais ramos em que tradicionalmente se dividiu a ciência jurídica.

Tratando da questão especificamente do ângulo da natureza jurídica das pessoas jurídicas, José Manoel Sérvulo Correia, após destacar a artificialidade de certas pretensões classificatórias, concluiu que "nenhum dos critérios de classificação propostos pela doutrina, ou mesmo fórmulas de combinação de vários de entre eles, asseguravam uma base sólida e consistente para arrumar as pessoas coletivas em públicas e privadas. Tinha já então a consciência de que esta circunstância reflectia uma realidade subjacente mais ampla: a da força da unidade do ordenamento jurídico e do carácter voluntarista e tentativo do esforço da sua seriação em torno dos pólos

1 Não temos, naturalmente, até pclo pouco debate doutrinário existente até o momento sobre o novo Código, a pretensão de esgotar todas as questões e possíveis interpretações que dele possam advir.

* Professor-Assistente do Mestrado da Faculdade de Direito da Universidade Candido Mendes. Professor das Pós-graduaçōes em Direito do Estado da U.E.R.J. e em Direito da Administração Pública da UFF. Mestre em Direito Público pela U.E.R.J. Doutorando em Direito do Estado pela U.S.P. Procurador do Estado e Advogado no Rio de Janeiro. Membro do IAB e do IBAP (alexaragao@zipmail.com.br). 
do público e privado. (...) A privatização do Direito Público e a publicização do Direito Privado reflectem um cair de barreiras entre Estado e sociedade, um aumento da complexidade intra-sistémica própria de uma pós-modernidade feita de proliferação de centros de poder e de produção de normas, de co-responsabilização do Estado e dos grupos na determinação das condições de realização dos interesses públicos."2

Se a divisão entre o Direito Público e o Direito Privado nunca pôde ser considerada absoluta, a partir, sobretudo, da década de 30 é, com efeito, cada vez mais relativa.

De um lado, o Direito Privado passou a sofrer um crescente dirigismo contratual, sendo cada vez mais presente a intervenção legislativa do Estado em relações privadas, principalmente naquelas de natureza econômica e consumeristas. "As novas situações de desigualdacle criadas por imensas transformações ensejaram um recuo no individualismo e uma ação enérgica do estado moderno, que passou a ser assistencial, buscando a elevação do nível de vida do indivíduo e a tutela do mesmo e da família, com a criação de institutos jurídicos sociais - os subsídios populares, o financiamento para aquisição de moradias, os direitos trabalhistas, a previdência social, o surgimento do crediário para fins de consumo. Dessa forma, ocorria o fenômeno conhecido como publicização do privado, ante à tentativa do Estado de restabelecer o equilíbrio do sistema". 3

O Direito Público, por sua vez, recebeu grande influxo privatístico, com a criação pelo Estado de entes de sua Administração Indireta revestindo formas jurídicas privadas, como as sociedades de economia mista - sociedades anônimas e as fundações e, mais recentemente, com a tentativa, às vezes frustrada pelo Supremo Tribunal Federal - STF, ${ }^{4}$ de adoção de mecanismos de gestão de Direito Privado como meio de atingir maior eficiência administrativa.

Este fenômeno, apesar de vetusto, revelaria inclusive uma das atuais acepções da "privatização", pela qual esta "traduz-se na atribuição ao Estado de formas ou instrumentos privados, ou seja, transforma-se 'o mecanismo específico ou singular, autoritário e de Direito Público, da intervenção do Estado num mecanismo jurídico-econômico em que o Estado se auto-atribui o regime jurídico comum ou se coloca numa posição idêntica à dos particulares'." 5

2 CORREIA. José Manoel Sérvulo. Fundações e Associações Públicas de Direito Privado, constante da obra coletiva "Os Caminhos da Privatização da Administração Pública - IV Colóquio Luso-Espanhol de Direito Adıninistrativo", Ed. Coimbra, Coimbra, 2001, pp. 301 e 302, grifamos. 3 LISBOA. Roberto Senise. Cuntratos Difusos e Coletivos, Ed. RT, $2^{\mathrm{a}}$ edição, São Paulo, 2000, p. 79.

4 Os arts. $1^{\circ}$ e $2^{\circ}$ da Lei $n^{\circ} 9.986 / 00$, por cxemplo, se encontram suspensos por liminar deferida pelo Supremo Tribunal Federal - STF em Ação Declaratória de Inconstitucionalidade (ADIN n ${ }^{\circ}$ 2.310-1/DF), que determinavan que os servidores das agências reguladoras seriam regidos pela CLT, ou seja, pelo regime trabalhista, comum, regido pelo direito privado.

5 ESTORNINHO, Maria João. A Fluga para o Direiro Privado, Ed. Almedina, Coimbra, 1999, p. 16. 


\section{II - As fundaçōes na teoria geral do direito e no direito privado}

Há uma série de institutos jurídicos que tradicionalmente - pela enorme sobrepujança que o Direito Civil ocupou nas ciências jurídicas até o advento do Estado Democrático de Direito no início do século XX — são ainda hoje didaticamente tratados como Capítulos dele integrantes, quando uma análise mais acurada e atualizada deveria colocá-los na Teoria Geral do Direito. ${ }^{6}$

Este é o caso das normas concernentes às pessoas jurídicas, ${ }^{7-8-9}$ especialmente às Fundações, que são institutos que podem ser instrumentalizados tanto por particulares em prol do interesse individual, como pelo Estado, para a persecução do interesse público. ${ }^{10}$

É sob esta perspectiva que a natureza jurídica das fundações instituídas pelo Poder Público deve ser enfocada, ou seja, sem um pré-conceito, sem uma tendência a priori para considerá-la como de Direito Privado e, portanto, reconduzível inexoravelmente ao Direito Civil.

Ainda que a legislação civil, a o que o novo Código Civil não constitui exceção (cf. art. 44, III), costume arrolar as fundações entre as pessoas jurídicas de Direito Privado, não podemos olvidar que o Código Civil não é a única fonte normativa que trata das fundações existindo uma enorme pletora de normas a respeito, desde normas constitucionais - algumas delas mais adiante analisadas - até outras normas de idêntica hierarquia legal, capazes, portanto, de manterem a sua vigência como normas especiais face ao Código ou de o derrogarem.

6 "As Fundações se apresentam como instituições absolutamente adaptadas e integradas no Estado Social: como manifestação dessa necessária inter-relação entre a sociedade civil e os poderes públicos; como expressão da participação dos particulares na consecução de fins de interesse geral" (MAÑAS, José Luis Piñar. Propuestas para una futura y posible Ley de Fundaciones. in Revista Española de Derecho Administrativo - REDA. versão CD-ROM).

7 "Em que pesem as dificuldades de fundamentação, as noções de sujeito jurídico, pessoa física e pessoa jurídica são correntes na dogmática” (FERRAZ JÚNIOR. Tércio Sampaio. Introdução ao Estudo do Dircito, Ed. Atlas, $2^{2}$ edição. São Paulo, 1994. p. 157).

8 Para as diversas Teorias que explicam a existência de pessoas jurídicas, sendo as principais a da Ficção, a Organicista e a Institucionalista, cuja análise nos desviaria demasiadamente dos nossos objetivos, remetemos o leitor a FRANCO MONTORO. André. Introdıção à Ciência do Direito, Ed. RT, $25^{2}$ edição, São Paulo, 1999, p. 500 e seguintes.

9 Os Códigos Civis tradicionalmente contém, inclusive, dispositivos enumerando também as pessoas jurídicas de Direito Público.

10 "A personalidade jurídica é recurso técnico, 'forma jurídica que a lei adota para dar regulamento unitário a múltiplas relações entre uma pluralidade de indivíduos ou base estável para o funcionamento de obras de interesse geral', ensina Ferrara. Os fins a que a personalidade jurídica atende são os mais diversos. A rigor, como acentua Ferrara. toda necessidade do homem, qualquer exigência da civilização pode determinar o nascimento de uma pessoa jurídica. O fim deve ser determinado, possível e lícito" (LIMA. Hermes, Introdução à Ciência do Dircito, Freitas Bastos Editora, 32a edição, Rio de Janeiro, 2000, p. 201). Aprofundar em CARNELUTTI. Francesco. Teoria Geral do Direito, Ed. Lejus, São Paulo, 2000, pp. 230 e 231. 
De acordo com o Código Civil, ou, dizendo mais propriamente, com as lições tradicionais da Teoria Geral do Direito, as fundações são personalizações jurídicas de patrimônios, ou seja, as fundações são o instrumento técnico-jurídico de, ao afetar determinada universalidade patrimonial a determinado objetivo não-lucrativo, ${ }^{11}$ personificá-lo através de um estatuto e de órgãos dirigentes para a consecução deste escopo. ${ }^{12}$

\section{III - As fundações no direito público}

Devemos ter em conta ao enfrentar o tema a que nos dispomos, que a Teoria das pessoas jurídicas em geral e especificamente das fundações foi desde a Idade Média construída tendo en vista, sobretudo, as relações privadas; apenas nos dois últimos séculos que a Teoria Geral do Direito começou a se debruçar sobre as chamadas pessoas jurídicas de Direito Público, ${ }^{13}$ notadamente as da Administração Pública Indireta, o que, sem dúvida, torna a matéria mais complexa e menos consolidada.

JOSÉ MANOEL SALA ARQUER afirma que o tema "se inscreve, com efeito, em um fenômeno - o das pessoas jurídicas públicas, distintas da Administração estatal - que nos situa, descle o início, diante de um panorama que demanda ser esclarecido. Poucas categorias como esta das 'formas personificadas' têm experimentado uma transformação mais intensa e acelerada, nem sempre acompanhada de idéias claras. Frente à relativa simplicidade dos 'tipos' que, não faz muito tempo, circulavam em nosso Direito Público, assistimos hoje a uma situação que podemos qualificar de caótica. Abusou-se das formas jurídicas, ao extremo em que em algumas ocasiões o Legislador parece um destes cientistas de laboratório, empenhado em experimentar estranhos 'cruzamentos', que às vezes dão lugar a híbridos e a criaturas monstruosas ou inviáveis. Há sociedades de titularidade pública que na realidade são simples centros administrativos encobertos ou disfarçados”. ${ }^{14}$

11 "Ao contrário dos outros tipos de pessoas jurídicas, as fundações não associam pessoas. Assentam-se num conjunto de bens, a que se atribui uma finalidade. A administração é mero instrumento dessa finalidade" (LIMA, Ilermes, Introdução à Ciência do Direito, Freitas Bastos Editora, $32^{a}$ edição, Rio de Janciro, 2000, p. 202).

12 A constituição de Fundaçōes deve, na forma do que dispõem o Código Civil e o Código de Processo Civil, se dar mediante as seguintes e sucessivas principais fases: (a) Lavratura de escritura pública de instituição da Fundação, incluindo o respectivo Estatuto; (b) Aprovação pelo Ministério Público; (c) Deferimento judicial para que seja feito o registro no Registro Civil das Pessoas Jurídicas; (d) Inscrição no Reģistro Civil das Pessoas Jurídicas, quando (e somente quando) a Fundação adquire personalidade jurídica.

13 "A noção de pessoa jurídica tem origem na Idade Média e na necessidade de conferir ao comércio das corporações, que então se organizavam, uma certa garantia jurídica. Havia problemas de responsabilidade que o indivíduo sozinho não suportava e a mera solidariedade não resolvia" (FERRAZ JÚNIOR, Tércio Sumpaio. Introdlução ao Estudo do Direito, Ed. Atlas, $2^{2}$ edição, São Paulo, 1994, p. 156). 
Pietro Perlingieri, de uma perspectiva um pouco mais otimista, justifica o surgimento de muitas destas entidades observando que "nascem e se proliferam porque a jurisdição não funciona, porque o Poder Executivo não sabe mais como organizar e fazer funcionar a máquina da Administração Pública, porque o Poder legislativo não consegue legislar tempestivamente". ${ }^{15}$

\section{III.I - A personalidade jurídica de Direito Público e a Descentralização} Administrativa

Como evolução/contraposição ao modelo centralista, napoleônico, de Administração Pública, ${ }^{16} \mathrm{em}$ um primeiro momento a autonomia no desempenho de parcelas das atividades estatais se deu através da criação pelo Estado de pessoas jurídicas a ele paralelas, denominadas entre nós de entidades da Administração Indireta. ${ }^{17}$

Vital Moreira ${ }^{18}$ observa que "na concepção tradicional a administração pública apresentava um perfil unitário, baseado nos serviços departamentais hierarquizados, na direç̧ão governamental e na responsabilidade parlamentar do Governo pela actividade da administração. O modelo originário da administração pública do Estado constitucional era a "administração ministerial", isto é, a administração hierarquicamente organizada sob a égide de um Ministro responsável. (...) Hoje a "unidade da administração é uma fíç̧ão", sendo incontroversa a sua natureza "plurifórmica e pluricêntrica", (...) o que constitui "resultado natural da passagem do Estado burguês oitocentista, tipicamente monoclassista", voltado exclusivamente para a proteção dos interesses da burguesia então vitoriosa, para o Estado pluriclasse contemporâneo" (sufrágio universal, acesso democrático aos cargos da administração pública, desenvolvimento dos sindicatos, prestações estatais positivas etc.), "que necessariamente reflete na sua organização o incontornável e crescente pluralismo da organização social. (...) O pluralismo social e político provocou o pluralismo e

14 SALA ARQUER, José Manocl. Las Fundaciones y Associaciones Públicas de derecho Privado: el caso de las fundaciones samitarias, constante da obra coletiva "Os Caminhos da Privatização da Administração Pública - IV Colóquio Luso-Espanhol de Direito Administrativo", Ed. Coimbra. Coimbra, 2001, p. 306.

15 PERLINGIERI, Pietro (a cura di). Authorities e Tutela della Persona, Edizioni Scientifiche Italiane. Napoli, 1999, p. 278.

16 Eduardo García de Enterría descreveu o modelo administrativo napoleônico da seguinte maneira: "as funções ativas se reservam apenas aos órgãos com agentes individuais ou monocráticos, os quais se relacionam entre si mediante a técnica do escalonamento hierárquico, enquanto que os órgãos colegiais ficam reduzidos a funções consultivas ou deliberativas situadas lateralmente à linha hierárquica, assistindo-a e complementando-it. mas sem diminuir a sua substantividade e prevalência” (in "Revolución Francesa y Administración Contemporánea". Civitas, 4" ed., 1998, p. 125). 17 ARAGÃO. Alexandre Santos de. As Agências Reguladoras e a Evolução do Direito Administrativo Econômico, Ed. Forense, Rio de Janeiro, 2002, pp. 201 e seguintes.

18 MOREIRA, Vital. Administração Autónoma e Associações Públicas, Coimbra, 1997, pp. 31/5 (grifos nossos). 
a diferenciação organizatória da administração." De outra forma, o Estado não poderia desempenhar suas atribuições com a agilidade e eficiência necessárias. ${ }^{19}$

A fórmula que, até o momento, mais obteve êxitos foi a descentralização administrativa através de órgãos ou entidades, geralmente especializados tecnicamente, dotados, em maior ou menor escala, de autonomia e que, atípicos em relação ao tradicional aparato administrativo hierarquizado, atuam com acentuado poder decisório.

Vital Moreira, citando Breuer, considera-os como a "resposta necessária do moderno Estado social ao alargamento das suas tarefas. A autonomização de organismos administrativos é, portanto, uma conseqüência, em termos de diferenciação e especialização, da ampliação e diversificação das tarefas administrativas."

Caracterizando a administração pública do Estado pluriclasse como "policêntrica", afirma que, "quanto mais a colectividade se especializa e diferencia técnicoprofissionalmente e se pluraliza ético-culturalmente, tanto menor se torna aquilo que é comum a todos e tanto maior necessidade existe de diferenciação político administrativa para corresponder à diversidade dos apelos feitos aos poderes públicos." 20

Naturalmente que nenhum modelo administrativo é inteiramente descentralizado ou centralizado. A adoção completa daquele levaria à desintegração da organização administrativa, e, a deste, à sua inviabilização prática. ${ }^{21}$

Classicamente, a descentralização é definida em contraposição à desconcentração.

A descentralização seria a criação de pessoas jurídicas pelo Estado e a desconcentração a mera divisão de funções entre os diversos órgãos despersonalizados de uma mesma pessoa jurídica estatal, ou seja, seria a criação de órgãos periféricos dentro da própria Administração Direta.

Estes conceitos tradicionais de descentralização e desconcentração, na época em que nenhuma das duas acarretava significativa autonomia, não eram propriamente incorretos. Todavia, não mais correspondem ao modelo administrativo efetivamente descentralizado exigido, e já implantado, pelo Estado contemporâneo. Podemos, contudo, nos valer de ambos os conceitos, desde que lhes seja acrescentado um plus ontológico. ${ }^{22}$

A mera criação de pessoa jurídica da Administração Indireta, sem que possua um grau de razoável autonomia para desenvolver suas atribuições, não tornará o seu

19 Cf. Hughes, Some Aspects of Development of American Law, 1916, 39, New York State Bar Association Reports, 266, 269.

20 MOREIRA, Vital. Administração Autónoma e Associações Públicas, Coimbra, 1997, pp. 30, 31 e 35.

21 Para uma análise sistemática dos diversos graus de centralização e descentralização, ver Méndez, in "Sistemas Orgánicos", constante da obra coletiva "Perspectivas del Derecho Público en la segunda Mitad del siglo XX”. Madrid, 1969, pp. 951/2 e 956/7.

22 ARAGĀO, Alexandre Santos de. As Agências Reguladoras e a Evolução do Direito Administrativo Econômico, Ed. Forense, Rio de Janeiro, 2002, pp. 201 e seguintes. 
desempenho mais ágil e eficiente. A desconcentração também é, por sua vez, mera forma de organização interna que não altera os vínculos hierárquicos tradicionais. Nenhuma delas, portanto, se tomadas nos seus conceitos tradicionais, constituirão necessariamente verdadeira descentralização.

Em todo o mundo, podemos constatar que a Administração Pública caminha para a descentralização em sentido material, sendo irrelevante a sua caracterização formal/tradicional, vista acima. O que importa é que a determinados centros de competência seja conferida considerável autonomia de atuação, independentemente deles serem constituídos ou não como pessoas jurídicas. ${ }^{23}$

Propugnando pela relativização dos conceitos formais de órgão e de pessoa jurídica administrativa e, conseqüentemente, de desconcentração e descentralização em sentido meramente formal, Gaspar Ariño Ortiz ${ }^{24}$ chega a observar que "o conceito estrito de pessoa jurídica, tal como elaborada pela pandectística do Direito Privado resultava insuficiente para dar fundamento à razão da organização administrativa; o estrito dualismo órgão-pessoa só era capaz de explicar parcialmente a pluralidade de figuras subjetivas que podiam atuar em Direito público de maneira juridicamente relevante. (...) Se pretenderá assim - digo - mediante a substituição da idéia unitária de 'pessoa' (sujeito), pelas idéias-base de 'capacidade', 'imputação' $e$ 'legitimação', que são elementos singulares daquela (capacidade para ser titular de direitos, para figurar em juízo, etc.)", alcançar um conceito material de ambos os institutos de molde a adequá-los às particularidades do Direito Público.

João Caupers afirma que a abordagem das fundações da Administração Pública é caracterizada pela "crescente consideração da personalidade jurídica como mero instrumento jurídico, não correspondente a uma realidade sociológica pré-determinada". ${ }^{25}$

Parte da doutrina afirma mesmo que os entes personalizados sem autonomia sequer podem ser considerados verdadeiras pessoas jurídicas. Por mais fortes razões, também não se poderia deles inferir qualquer descentralização. Ambas as categorias, centrais no mundo do Direito Administrativo, estariam falseadas.

Neste sentido é que Garrido Falla, seguindo Ferrara, fala de "pessoas jurídicas fictícias", ${ }^{26}$ desprovidas de substrato real, ou seja, de um regime jurídico que realmente as trate como tal, que lhes confira um grau razoável de liberdade de agir.

23 ARAGÃO, Alexandre Santos de. As Agências Reguladoras e a Evolução do Direito Administrativo Econômico, Ed. Forense, Rio de Janeiro, 2002, pp. 201 e seguintes.

24 ORTIZ, Gaspar Ariño. La Administración Institucional - Bases de su regimen jurídico, Instituto de Estudios Administrativos, Madrid, 1972, pp. 32/3, grifamos.

25 CAUPERS, João. As Fundações e as Associações Públicas de Direito Privado, constante da obra coletiva "Os Caminhos da Privatização da Administração Pública - IV Colóquio Luso-Espanhol de Direito Administrativo", Ed. Coimbra, Coimbra, 2001, p. 324, grifos nossos.

26 Apud ORTIZ, Gaspar Ariño. La Administración Institucional - Bases de su regimen jurídico, Instituto de Estudios Administrativos, Madrid, 1972, pp. 404/5. 
Adotando o conceito material (efetivo, verdadeiro...) de descentralização, Alfredo Gallego Anabitarte ${ }^{27}$ pronunciou-se no sentido de que "também se pode produzir a verdadeira descentralização em um sujeito ou centro de competências que não seja personalizado. (...) Não é essencial à descentralização que o sujeito descentralizado seja titular da competência que se the transfere (...). A usual definição de descentralização como "transferência da titularidade de competências entre pessoas jurídicas" não é mais que uma das hipóteses - a mais usual — de descentralização. Por outro lado, pode produzir-se esta transferência entre pessoas jurídicas como o caso das entidades da Administração Indireta, mas pode, todavia, não haver verdadeira descentralização em virtude da completa, e lógica tutela, a que se submete a atuação destas pessoas jurídicas."

Postos os conceitos e as discussões fundamentais acerca da descentralização administrativa e da Administração Indireta. passamos, no Item seguinte, a apreciar especificamente as fundações integrantes da Administração Pública, que constituem uma das mais importantes manifestações dos institutos acima analisados, e que, em sendo assim, não podem ser enfocadas à luz apenas (ou preponderantemente) do Direito Civil.

\section{III.2 - Natureza Jurídica das Fundaçōes Públicas}

Neste Item, adentraremos, portanto, nas discussões acerca da natureza Jurídica das Fundações Públicas, ou seja, instituídas pelo Poder Público. ${ }^{28}$

Apesar das celeumas doutrinárias quanto ao rol das entidades da Administração Indireta, devemos partir da Constituição Federal e da consolidação legislativa (cf., sobretudo, Decreto-lei $n^{\circ}$ 200/67) existente na matéria, já absorvida pela maior parte da doutrina, que, juntamente com as Fundações Públicas ou instituídas pelo Poder Público, reúne as Autarquias, as Empresas Públicas e as Sociedades de Economia Mista na Administração Indireta. Estas duas são indubitavelmente de Direito Privado, ao passo que as autarquias são incontroversamente pessoas jurídicas de Direito Público $^{29}$. As discussões se deitam apenas sobre a natureza jurídica das Fundações Públicas, se de Direito Privado ou público.

27 ANABITARTE, Alfredo Gallego. Transferencia y Descentralización; Delegación y Desconcentración; Mandato y Gestión o Encomienda. Teoría Jurídica y Derecho positivo, constante da obra coletiva "Actualidad y Perspectivas del Derecho Publico a fines del siglo XX - Homenaje al Profesor Garrido Falla". Editorial Complutense, pp. 552/3.

28 O fato de serem denominadas de fundações públicas não pode representar qualquer pré-conceituação no sentido de serem pessoas jurídicas de Direito Público. A alcunha se refere à característica de pertencerem à Administração Pública Indireta, tal como as empresas públicas, a cuja personalidade jurídica de direito privado não se dissente.

29 Como são de direito público e exercem funções administrativas típicas, ou sejam, funções dotadas de imperatividade - possibilidade ex lege de imposição unilateral aos indivíduos - todas as prerrogativas da Administração Pública lhes são naturalmente extensivas. Também os seus atos são administrativos, sujeitando-se aos controles característicos (mandado de segurança etc.). Os 
As controvérsias, sobre as quais o novo Código Civil traz novos elementos são de grande importância, não apenas teórica, como prática, inclusive no que toca à execução por precatórios (exclusiva da Fazenda Pública), às prerrogativas processuais da Fazenda Pública (ex.: prazos maiores para contestar e recorrer) e ao Juízo competente (ex.: as Varas de Fazenda Pública da Justiça Estadual).

$\mathrm{O}$ advento das entidades da Administração Indireta e o surgimento de suas espécies acompanharam o desempenho de novas atividades pelo Estado. Foi a ampliação das funções do Estado no meio social e econômico, agindo muitas vezes diretamente no domínio econômico e social. que exigiu a adoção de novos instrumentos institucionais. Não seria recomendável, por exemplo, que o Estado assumisse a função de fabricante de aviões através da Administração Direta.

É assim que a especialização e o surgimento de novas funções do Estado, notadamente na área de fiscalização de setores econômicos, levou à criação das autarquias; as funções sociais e de fomento específicas passaram a muitas vezes serem desempenhadas por fundações públicas; e a exploração de atividades econômicas ou de serviços públicos com conteúdo econômico coube principalmente às empresas públicas e sociedades de economia mista.

As Fundações integrantes da Administração Indireta devem ser analisadas tendo-se em vista as numerosas disposições constitucionais que as têm como objeto, e que, naturalmente, devem ser o filtro pelo qual devem ser interpretadas as leis infraconstitucionais, entre elas o Código Civil recém editado. ${ }^{30}$

São numerosas as controvérsias acerca da natureza jurídica destas entidades da Administração Indireta, previstas nos artigos 62 e seguintes do Código Civil como patrimônios personificados pela sua finalidade.

A alusão da CF/88 a uma "administração fundacional" (arts. 37, XI e 38) levou alguns até a defenderem que não integrariam a Administração Indireta, mas, como demonstra Odete Medaur, tratou-se apenas de uma cautela do Constituinte, para que as fundações não continuassem a ser usadas para evitar a aplicação de normas isonômicas e moralizadoras da Administração Pública. ${ }^{31}$

No que diz respeito à própria possibilidade de instituição de fundações pelo Estado, encontramos do Direito Comparado várias posturas: o Direito Belga veda

seus bens são públicos para todos os efeitos e se beneficiam dos privilégios processuais concernentes à "Fazenda Pública".

30 Destaca-se, a este respeito, na própria seara do Direito Privado, a insurgência do Direito Civil Constitucional, cuja construção teórica no Brasil é em grande monta devida a Gustavo Tepedino (entre outros textos, ver $O$ Código Civil, os chamados microssistemas e a Constituição: premissas para uma reforma legislativa, constante da obra coletiva Problemas de Direito Civil Constitucional, Ed. Renovar, Rio de Janeiro, 2000, coordenada pelo próprio autor citado, pp. 17/54). Ora, se acertadamente passou-se a ter a consciência de que todo o Direito Civil deve ser interpretado e aplicado à luz dos princípios e valores constitucionais, quiçá o instituto das Fundaçōes instituídas pelo Poder Público, a respeito das quais há regras e princípios constitucionais específicos e explícitos.

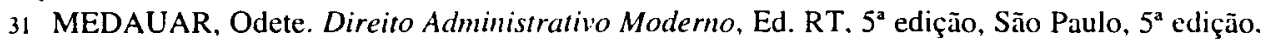
2001, pp. 87 e 88 . 
expressamente a instituição de fundações pelo Poder Público; ${ }^{32}$ em França, Georges Ripert faz referência às missões de serviço público assumidas por entidades privadas, admitindo-se genericamente que entidades da Administração Pública possam revestir formas jurídicas oriundas das categorias clássicas do Direito Privado; ${ }^{33}$ na Alemanha não se questiona a possibilidade do Estado instituir Fundações, que são tratadas sem maiores questionamentos nos manuais de Direito Administrativo; ${ }^{34}$ em Portugal Vital Moreira, escrevendo antes da existência de norma positiva expressa no sentido da admissibilidade da sua instituição, assinalava que, diante da ausência de vedação constitucional, poder-se-ia admitir a criação de fundações pelo Estado para perseguir fins públicos, fazendo, contudo, ressalvas quanto à excepcionalidade da administração pública por entes privados, à impossibilidade da sua atuação em algumas tarefas e à ilegitimidade da sua utilização como estratagema para escapar das normas fundamentais da Administração Pública, principalmente no que diz respeito aos seus controles: ${ }^{35}$ no Direito Espanhol, bastante restritivo quanto à possibilidade em foco, Parejo Alfonso observa que os problemas em se admitir a criação de fundações pelo Poder Público está na dificuldade em se separar, como a lei civil exige, a criatura (a fundação) do criador (Ente estatal fundador), "uma vez que tal só poderia decorrer de um 'abandono definitivo' pelo ente público dos interesses públicos de cuja consecução a lei o encarregou". ${ }^{36}$

No Direito Brasileiro, a exemplo do acima visto em relação ao Direito Alemão, a doutrina parte, sem maiores questionamentos, do pressuposto da possibilidade de o Poder Público instituir fundações, deitando-se as discussões, e aqui elas abundam, apenas sobre a sua natureza jurídica.

32 Cf. BANMEYER, Ilse e TALBOT, Cindy. Les Fondations:état présent et idées de réforme, in Annales de Louvain, $\mathrm{n}^{\circ}$ 1, 1998, p. 29.

33 Cf. CAUPERS, João. As Fundações e as Associações Públicas de Direito Privado, constante da obra coletiva "Os Caminhos da Privatização da Administração Pública - IV Colóquio LusoEspanhol de Direito Administrativo", Ed. Coimbra, Coimbra, 2001, p. 325. GAUDEMET assinala que a participação de entidades públicas na criação de fundações é uma constante na França. Distingue, todavia, entre fundações em cuja criação toma parte, junto com outros fundadores, a Administração, e fundações em cuja constituição só participa uma pessoa jurídico-pública. É neste segundo caso que existem problemas. Em qualquer caso, aponta, há neste tema um completo empirismo: 'La théorie n'en est pas faite' (Yves GAUDEMET, La crèation des fondations par les personnes publiques ou d'utilité publique, in Le droit des fondations en France et à l'etranger. volume dirigido por R J. DUPUY, Notes et Etudes Documentaires, núm. 4879, 1989-4. pp. 47 e segs., apud MAÑAS, José Luis Piñar. Fundaciones constituidas por entidades públicas. Algunas cuestiones, in Revista Española de Derecho Administrativo - REDA, versão CD-ROM.).

34 Cf. CAUPERS, João. As Fundações e as Associações Públicas de Direito Privado, constante da obra coletiva "Os Caminhos da Privatização da Administração Pública - IV Colóquio LusoEspanhol de Direito Administrativo", Ed. Coimbra, Coimbra, 2001, pp. 325/6.

35 MOREIRA, Vital. Administração Autônoma e Associações Públicas, Coimbra Editora, Coimbra, 1997, pp.286/7.

36 Cf. CAUPERS, João. As Fundações e as Associações Públicas de Direito Privado, constante da obra coletiva "Os Caminhos da Privatização da Administração Pública - IV Colóquio LusoEspanhol de Direito Administrativo", Ed. Coimbra, Coimbra, 2001, p. 329. 
O Código Civil de 1916 previu as fundações com a perspectiva de serem todas instituídas por particulares, o que não era de se espantar diante do momento histórico em que foi editado, em que o Estado ainda exercia reduzida intervenção nos âmbitos social e econômico. O novo Código Civil, todavia, não mudou muito a situação, se referindo tout court às fundações como pessoas jurídicas de direito privado. Também o art. $5^{\circ}$, I do Decreto-lei $n^{\circ} 200 / 67$ as qualifica como pessoas jurídicas de direito privado.

Autores há que sustentam que a personalidade jurídica de direito privado é ínsita ao próprio conceito de fundação; que fundação de direito público não é, na verdade, fundação. ${ }^{37}$

Outra corrente entende, ao revés, que todas as fundações instituídas pelo Poder Público possuem personalidade jurídica de Direito Público, equiparando-as, por esta razão, às autarquias. ${ }^{38}$

A doutrina majoritária, a qual integramos, sustenta que as fundações públicas podem ser de direito privado ou de direito público, e que, neste caso, estariamos diante de espécies de autarquias - autarquias fundacionais ou fundações autárquicas. ${ }^{39}$

Esta é a posição que, não sem certa hesitação, foi adotada pelo Supremo Tribunal Federal - STF, que tem equiparado algumas fundações instituídas pelo Poder Público às autarquias, sobretudo nos casos em que a fundação depende de verbas públicas, ou seja, que não possuem o traço - característico das fundações na Teoria Geral do Direito - de personificação de um patrimônio que, por si só e por seus frutos, seja capaz de propiciar o atingimento dos seus objetivos institucionais.

No leading case ( $\mathrm{RE} \mathrm{n}^{\circ}$ 101.126-RJ, Rel. Min. Moreira Alves) o Supremo Tribunal Federal - STF assentou:

"Nem toda fundação instituida pelo Poder Público é fundação de direito privado. As fundações, instituidas pelo Poder Público, que assumem a gestão de serviço estatal e se submetem a regime administrativo previsto, nos Estados-membros, por leis estaduais, são fundações de Direito Público, $e$, portanto, pessoas jurídicas de Direito Público. Tais fundaçōes são espécie do gênero autarquia".

37 Verbi gratia, FRANCO SOBRINHO, Manoel Oliveira, RDA, 25/287.

38 Cf. BORGES, José Arthur Diniz, Direito Administrativo Sistematizado e sua Interdependência com o Direito Constitucional, Ed. Lumen Juris, Rio de Janeiro, 2002, p. 49.

39 DI PIETRO, Maria Sylvia Zanella, Direito Administrativo, Ed. ATLAS, São Paulo, $13^{a}$ edição, 2001, pp. 364/7 e MEDAUAR. Odete. Direito Administrativo Moderno, Ed. RT, 5 a edição, São Paulo, $5^{2}$ edição, 2001 , pp. 89 e 90 . Esta não concorda, contudo, que a fundação de Direito Público possa ser equiparada às autarquias, uma vez que não faria sentido que a Constituição previsse estas duas espécies de entidades da Administração Indireta se elas, substancialmente, fossem equivalentes. 
Em outro julgado, mais recente ( $\operatorname{RE~n}^{\circ} 215.741$, Rel. Min. Maurício Corrêa), o Supremo Tribunal Federal - STF manteve a sua orientação através da seguinte ementa:

"Fundação Pública - Autarquia - Justiça Federal.

1. A Fundação Nacional de Saúde, que é mantida por recursos orçamentários oficiais da União e por ela instituída, é entidade de Direito Público.

2. Conflito de competências entre Justiça Comum e Federal. Artigo 109. I, da Constituição Federal. Compete à Justiça Federal processar e julgar ação em que figure como parte fundação pública, tendo em vista sua natureza jurídica conceitual assemelhar-se, em sua origem, às autarquias.

3. Ainda que o Artigo 109, I, da Constituição Federal, não se refira expressamente às fundações, o entendimento desta Corte é o de que a finalidade, a origem dos recursos e o regime administrativo de tutela absoluta a que. por lei, estão sujeitas, fazem delas espécie do gênero autarquia.

4. Recurso Extraordinário conhecido e provido para declarar a competência da Justiça Federal."

Da análise da jurisprudência do Supremo Tribunal Federal - STF constata-se que a Corte estabelece uma série de "indícios", cuja presença, mais ou menos intensa, identifica uma fundação instituída pelo Poder Público como pessoa jurídica de Direito Público. Dentre estes indícios figura, todavia, com preponderância, o fato de não ser sustentada por receitas próprias, mas sim com recursos do Ente federado instituidor. ${ }^{40}$

Partindo dos pressupostos postos pela corrente majoritária, coincidente com os fixados pelo Supremo Tribunal Federal - STF, quando a fundação for de direito público, aplicar-se-á a disciplina jurídica característica das autarquias, inclusive no que diz respeito à sua instituição, feita diretamente por lei, aplicando-se-lhes todas as prerrogativas típicas das pessoas jurídicas de direito público, salvo disposição legal em contrário.

Quanto às fundações públicas de direito privado, o Decreto-lei n $200 / 67$ é contraditório: no art $5^{\circ}$, IV, afirma que as fundações públicas são pessoas jurídicas de direito privado; no $\S 3^{\circ}$ do mesmo artigo diz que, ressalvada a constituição pelo registro próprio, não aplicar-se-lhe-ão, as normas do Código Civil referentes às fundações. Sendo assim, não são controladas pelo Ministério Público, mas pelo Ente político instituidor, uma vez que, ao contrário do que se dá nas fundações particulares, a vontade do instituidor não se desliga de forma definitiva da fundação. ${ }^{41}$ Da mesma

40 CARVAlHo FILHO, José dos Santos. Manual de Direito Administrarivo, Ed. Lumen Juris, Rio de Janeiro, $7^{\mathbf{a}}$ edição, 2001, pp. 389 e 400.

41 "Com relação às fundações instituídas por particulares, a função do Ministério Público justifica-se pela necessidade de atribuir a algum órgão público a função de manter a entidade dentro dos objetivos para os quais foi instituída; vale dizer, como a fundação adquire vida própria e nela não mais interfere o instituidor, o Ministério Público assume essa função. Nas fundações públicas ou 
forma, a lei poderá extinguir ou modificar o regime jurídico da fundação pública, ainda que de Direito Privado, independentemente de qualquer ato social interno desta.

As fundações instituídas pelo Poder Público que forem de direito privado têm apenas as características privatísticas que não decorram do Código Civil: os seus bens são, penhoráveis, ressalvados os afetados a serviços públicos; a sua responsabilidade não é objetiva, salvo se for prestadora de serviços públicos; e o seu pessoal será necessariamente regido pela $\mathrm{CLT}$. $^{42}$

Submeter-se-ão, contudo, como qualquer pessoa jurídica da Administração Indireta - de direito público ou privado - às normas constitucionais asseguradores da igualdade e moralidade da Administração Pública, como a criação autorizada em lei (art. 37, XIX, CF), a vedação de acumulação de cargos, controle pelo Tribunal de Contas, teto remuneratório, licitações, vedação da publicidade de promoção pessoal etc. (art. 37, CF).

\section{IV - O novo Código Civil}

Neste derradeiro Tópico. visamos analisar a forma com que se dá o encontro com o novo Código Civil do acúmulo doutrinário e jurisprudencial de Direito Administrativo (cf. Tópico anterior) consolidado sob a vigência do Código Civil de 1916, editado antes de o Estado começar a proliferar as suas Fundações. ${ }^{43}$

privadas, instituídas pelo Poder Público, a autonomia da entidade não vai ao ponto de as desvincular inteiramente dos laços que a prendem ao ente instituidor; este se encarrega de manter essa vinculação por meio do controle interno (tutela) exercido pelos órgãos da Administração Direta" (DI PIETRO, Maria Sylvia Zanella, Direito Administrativo, Ed. ATLAS, São Paulo, $13^{a}$ edição, 2001, p. 369). 42 Note-se que, até a Reforma Administrativa (EC 19/98), havia a obrigatoriedade de regime jurídico único de pessoal - necessariamente, segundo o entendimento que foi predominante, de Direito Público, isto é, estatutário - para a Administração Direta, autarquias e fundações públicas. A colocação, para este efeito, das Fundações Públicas juntamente com os entes Federados (Administração Direta) e as autarquias, de fato dava argumentos ao entendimento pelo qual todas deveriam ser de Direito Público. Hoje. com o fim da obrigatoriedade do regime jurídico único e com a nova redação (EC 19/98) dada ao inciso XIX do art. 37, apartando as fundações públicas das autarquias e colocando-as juntamente corn as empresas públicas e sociedades de economia mista no que diz respeito à necessidade de lei específica autorizativa da sua instituição (não. como se dá com as autarquias. diretamente instituidora), novo alento recebem as outras duas correntes acima analisaldas. Entendemos, contudo, que a interpretação do art. 37, XIX, CF, não pode chegar ao ponto de apenas admitir fundações públicas de Direito Privado. uma vez que às fundações públicas de Direito Público, como espécic de autarquia que são, seria aplicada a disciplina dos entes autárquicos (por exemplo, a própria primeira parte do inciso XIX do art. 37 da Constituição Federal).

43 Em lição de todo aplicável ao Direito Brasileiro, José Luis Piñar Mañas, observa que "o fenômeno não é novo, mas o é o fato de que nunca antes como agora se tinha se dado com tamanha intensidade. Pode quase se dizer que, raro é o dia em que não se constitui $\mathrm{cm}$ algum lugar uma fundação por entidades públicas. Seguramente é a instituição fundacional a que hoje se está mostrando como a mais idônea para articular a recorrente 'fuga do Direito administrativo' (MAÑAS, José Luis Piñar. Fundaciones constituidas por entidades públicas. Algunas cuestiones, in Revista Española de Derecho Administrativo - REDA. versão CD-ROM). 
Não tendo, até pela novidade das questões que estão sendo apresentadas pelo novo Código, pretensões a esgotar o tema, julgamos conveniente analisar, à luz dos pilares teóricos já fixados, cada um dos artigos do Código Civil de 2002 que possam trazer consequêencias para a disciplina das Fundações instituídas pelo Poder público. Vejamo-los:

Art. 41. São pessoas jurídicas de direito público interno:

I - a União;

II - os Estados, o Distrito Federal e os Territórios;

III — os Municípios:

IV - as autarquias;

$\mathrm{V}$ - as demais entidades de caráter público criadas por lei.

Parágrafo único. Salvo disposição em contrário, as pessoas jurídicas de direito público, a que se tenha dado estrutura de direito privado, regem-se, no que couber, quanto ao seu funcionamento, pelas normas deste Código.

Art. 44. São pessoas jurídicas de direito privado:

I - as associações;

II — as sociedades;

III - as fundações.

Podemos ver que o novo Código Civil não resolveu a confusão existente em relação à natureza jurídica das fundações públicas, acabando, outrossim, por aumentá-la ainda mais: diante da omissão em incluir fundações públicas no rol das pessoas jurídicas de Direito Público (art. 41 ) e da inclusão das fundações em geral no elenco das pessoas jurídicas de Direito Privado (art. 44), há o entendimento segundo o qual, finalmente, foi definida a questão em favor da tese da personalidade jurídica de Direito Privado de todas as fundações da União, dos Estados e dos Municípios; enquanto outros, entre os quais nos incluímos, acham que continua existindo o mencionado poder de escolha do Legislador na definição da natureza jurídica das Fundações Públicas.

Com efeito, o próprio Código Civil menciona a existência de "demais entidades de caráter público criadas por lei" (art. 41, V) e a possibilidade de se dar estrutura de Direito Privado a pessoas jurídicas de Direito Público (art. 4l. Parágrafo único). Motivos práticos também militam em favor desta tese, uma vez que a outra posição faria com que todas as fundações de Direito Público, de todas as esferas da Federação, devessem sofrer profundas alterações em seus regimes jurídicos, inclusive em suas respectivas leis instituidoras, que constituem emanações da autonomia administrativa federativa constitucionalmente assegurada.

$$
* * *
$$

Art. 62. Para criar uma fundação, o seu instituidor fará, por escritura pública ou testamento, dotação especial de bens livres, especificando o fim a que 
se destina, e declarando, se quiser, a maneira de administrá-la.

Parágrafo único. A fundação somente poderá constituir-se para fins religiosos, morais, culturais ou de assistência.

O Parágrafo único do art. 62 constitui uma das maiores perplexidades da doutrina e da sociedade em geral com o novo Código Civil. De fato, ele reduz de forma inusitada o possível campo de atuação das fundações, contrariando todas as tendências de expansão do Terceiro Setor.

Entendemos, contudo, com MARCOS JURUENA VILLELA SOUTO, ${ }^{44}$ que o campo de atuação das fundações do Poder Público só pode ser definido pela lei complementar prevista na parte final do inciso XIX do art. 37 da Constituição Federal, ${ }^{45}$ não pelo Código Civil - lei ordinária.

Art. 2.031. As associações, sociedades e fundações, constituídas na forma das leis anteriores, terão o prazo de um ano para se adaptarem às disposições deste Código, a partir de sua vigência; igual prazo é concedido aos empresários.

Art. 2.032. As fundações, instituídas segundo a legislação anterior, inclusive as de fins diversos dos previstos no parágrafo único do art. 62 , subordinamse, quanto ao seu funcionamento, ao disposto neste Código.

Art. 2.033. Salvo o disposto em lei especial, as modificações dos atos constitutivos das pessoas jurídicas referidas no art. 44 , bem como a sua transformação, incorporação, cisão ou fusão, regem-se desde logo por este Código.

Os dispositivos transcritos, integrantes das Disposições Finais e Transitórias do novo Código Civil, deixam bem claro que as pessoas jurídicas constituídas antes da sua vigência também se submetem a ele, apenas possuindo o prazo de um ano para se adaptarem. Assim, por exemplo, se a posição atualmente dominante acerca da natureza jurídica das Fundações Públicas vier a ser alterada no sentido de que não mais possam existir fundações públicas de Direito Público, todas as que existirem

44 Palestra proferida no Seminário O Novo Código Civil, promovido pela Procuradoria Geral do Estado do Rio de Janeiro em 2002.

45 Art. 37. A administraçāo pública direta e indireta de qualquer dos Poderes da União, dos Estados, do Distrito Federal e dos Municípios obedecerá aos princípios de legalidade, impessoalidade, moralidade, publicidade e eficiência e, também, ao seguinte: XIX - somente por lei específica poderá ser criada autarquia e autorizada a instituição de empresa pública, de sociedade de economia mista e de fundação, cabendo à lei complementar, neste último caso, definir as áreas de sua atuação. 
deverão ser extintas ou modificadas, inclusive com a revogação das respectivas leis instituidoras.

É este ponto que nos parece tornar improvável a alteração do entendimento ora dominante, já que esta alteração faria com que devêssemos admitir que uma lei ordinária federal - o Código Civil - incidisse, sem qualquer autorização constitucional, diretamente sobre leis de todos os Entes da Federação (as leis instituidoras de fundações públicas de Direito Público).

Não menosprezamos o fato de a Constituição Federal atribuir competência privativa para a União legislar sobre Direito Civil (art, 22, I, CF), mas esta competência não pode legitimar a interferência da União no núcleo essencial da autonomia administrativa dos demais Entes federados, ${ }^{46}$ mormente quando a própria Constituição estabelece veículo legislativo específico no caso das Fundações Públicas (Lei Complementar - art. 37. XIX, in fine, $\mathrm{CF}$ ) para esta ingerência.

\section{$V-$ Conclusão}

Diante das lições doutrinárias e jurisprudenciais de Direito Administrativo e da pouca doutrina civilista até o momento existente sobre o objeto do presente estudo, entendemos que pouco mudou no regime jurídico das Fundações Públicas com o advento do novo Código Civil, estando mantida a possibilidade de o Legislador, à luz dos parâmetros fixados pelo Supremo Tribunal Federal - STF, caracterizar a Fundação Pública como ente de Direito Público ou Privado.

\section{$V I-$ Bibliografia}

ANABITARTE, Alfredo Gallego. Transferencia y Descentralización; Delegación y Desconcentración; Mandato y Gestión o Encomienda. Teoria Jurídica y Derecho positivo, in Actualidad y Perspectivas del Derecho Publico a fines del siglo XX - Homenaje al Profesor Garrido Falla, Editorial Complutense.

ARAGÃO, Alexandre Santos de. As Agências Reguladoras e a Evolução do Direito Administrativo Econômico, Ed. Forense, Rio de Janeiro, 2002.

BANMEYER, Ilse e TALBOT, Cindy. Les Fondations: état présent et idées de réforme, in Annales de Louvain, $\mathrm{n}^{\circ}$ 1, 1998.

BORGES, José Arthur Diniz. Direito Administrativo Sistematizado e sua Interdependência com o Direito Constitucional, Ed. Lumen Juris, Rio de Janeiro, 2002.

CARNELUTTI, Francesco. Teoria Geral do Direito, Ed. Lejus, São Paulo, 2000.

46 Pelo Princípio Federativo, cláusula pétrea da nossa Constituição (art. 60, $\$ 4^{\circ}, \mathrm{I}, \mathrm{CF}$ ), os aspectos administrativos e organizacionais de cada Ente Federativo recaem em suas respectivas esferas competenciais, legislativas e materiais. Este princípio pode, naturalmente, ser ilidido por outra norma constitucional que disponha, clara e especificamentc. em sentido contrário (ex.: arts. 22. XXVII, e 37, XIX, in fine, CF). 
CARVAlHo FILHO, José dos Santos. Manual de Direito Administrativo, Ed. Lumen Juris, Rio de Janeiro, $7^{\mathrm{a}}$ edição, 2001.

CAUPERS, João. As Fundações e as Associações Públicas de Direito Privado, in Os Caminhos da Privatização da Administração Pública - IV Colóquio LusoEspanhol de Direito Administrativo, Ed. Coimbra, Coimbra, 2001.

CORREIA, José Manoel Sérvulo. Fundações e Associações Públicas de Direito Privado, constante da obra coletiva "Os Caminhos da Privatização da Administração Pública - IV Colóquio Luso-Espanhol de Direito Administrativo", Ed. Coimbra, Coimbra, 2001.

DI PIETRO, Maria Sylvia Zanella, Direito Administrativo, Ed. ATLAS, São Paulo, $13^{a}$ edição, 2001

ENTERRÍA, Eduardo García. Revolución Francesa y Administración Contemporánea". Civitas. $4^{\text {a }}$ ed., 1998.

ESTORNINHO, Maria João. A Fuga para o Direito Privado, Ed. Almedina, Coimbra, 1999.

FERRAZ JÚNIOR, Tércio Sampaio. Introdução ao Estudo do Direito, Ed. Atlas, $2^{a}$ edição, São Paulo, 1994.

FRANCO MONTORO, André. Introdução à Ciência do Direito, Ed. RT, $25^{\text {a }}$ edição, São Paulo, 1999.

FRANCO SOBRINHO, Manoel Oliveira, RDA, 25/287.

GAUDEMET, Yves. La crèation des fondations par les personnes publiques ou d'utilité publique, in Le droit des fondations en France et à l'etranger, volume dirigido por R J. DUPUY, Notes et Etudes Documentaires, núm. 4879, 1989-4.

HUGHES, Some Aspects of Development of American Law, 1916, 39, New York State Bar Association Reports.

LIMA, Hermes, Introdução à Ciência do Direito, Freitas Bastos Editora, 32 edição, Rio de Janeiro, 2000.

LISBOA, Roberto Senise. Contratos Difusos e Coletivos, Ed. RT, $2^{\mathrm{a}}$ edição, São Paulo, 2000.

MAÑAS, José Luis Piñar. Fundaciones constituidas por entidades públicas. Algunas cuestiones, in Revista Española de Derecho Administrativo - REDA, versão CD-ROM.

- Propuestas para una futura y posible Ley de Fundaciones, in Revista Española de Derecho Administrativo - REDA, versão CD-ROM.

MEDAUAR, Odete. Direito Administrativo Moderno, Ed. RT. $5^{\text {a }}$ edição, São Paulo,

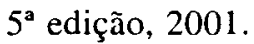

MÉNDEZ. Sistemas Orgánicos, in Perspectivas del Derecho Público en la segunda Mitad del siglo XX, Madrid, 1969.

MOREIRA, Vital. Administração Autónoma e Associações Públicas, Coimbra, 1997. ORTIZ, Gaspar Ariño. La Administración Institucional - Bases de su regimen jurídico, Instituto de Estudios Administrativos, Madrid, 1972.

PERLINGIERI, Pietro (a cura di). Authorities e Tutela della Persona, Edizioni Scientifiche Italiane, Napoli, 1999.

SALA ARQUER, José Manoel. Las Fundaciones y Associaciones Públicas de derecho Privado: el caso de las fundaciones sanitarias, in Os Caminhos da Pri- 
vatização da Administração Pública - IV Colóquio Luso-Espanhol de Direito Administrativo, Ed. Coimbra, Coimbra, 2001.

SOUTO, Marcos Juruena Villela. Palestra proferida no Seminário O Novo Código Civil, promovido pela Procuradoria Geral do Estado do Rio de Janeiro em 2002. TEPEDINO, Gustavo (coordenador). Problemas de Direito Civil Constitucional, Ed. Renovar, Rio de Janeiro, 2000. 